\title{
Evaluation of Clinical and Laboratory Findings and Diagnostic Difficulties in Children with Vitamin B12 Deficiency
}

\author{
Vitamin B12 Eksikliği Olan Çocuklarda Klinik ve Laboratuvar Bulguların ve Tanısal Zorlukların \\ Değerlendirilmesi
}

CCüneyt Karagöl' ${ }^{1}$, Metin Yiğit ${ }^{1}$

'University of Health Sciences, Ankara City Hospital, Department of Pediatrics, Ankara, Turkey

\section{ABSTRACT}

Aim: In this study, we evaluated the clinical and laboratory data of healthy children with vitamin B12 deficiency. The benefits of methylmalonic acid (MMA) and homocysteine levels and the difficulties encountered in diagnosing vitamin B12 deficiency were pointed out.

Material and Method: A total of 70 healthy children whose serum cobalamin levels were below $126.5 \mathrm{pg} /$ $\mathrm{ml}$ were included in the study. The age, gender, serum vitamin B12, urine MMA, plasma homocysteine, white blood cell, hemoglobin, thrombocyte, main corpuscular volume (MCV), main platelet volume (MPV), folic acid, and ferritin levels were obtained retrospectively from the hospital's medical records. The correlation analysis test compared vitamin B12 with MMA and homocysteine.

Results: The mean age was $8.21 \pm 6.15$ years, and vitamin B12 deficiency was found in $6.29 \%$ of healthy children. Cobalamin levels ranged from $50-126 \mathrm{pg} / \mathrm{ml}$, with a mean of $102.57 \pm 18.97 \mathrm{pg} / \mathrm{ml}$. Urine MMA and serum homocysteine levels were $0.59 \pm 0.67 \mathrm{ng} / \mathrm{ml}$ and $13.50 \pm 0.67 \mathrm{~g} / \mathrm{dl}$, respectively. The correlation coefficient value $(r)$ was found to be -0.342 and -0.437 , moderately negative for MMA and homocysteine, respectively. MMA levels were normal in 36 patients, and homocysteine levels were normal in 48 patients.

Conclusion: Vitamin B12 deficiency is a common micronutrient deficiency in children. The diagnosis of vitamin B12 deficiency can be complex in healthy children who do not display typical laboratory findings, particularly elevated MMA and homocysteine.

Keywords: Vitamin B12 vitamini, kobalamin, metilmalonik asit, homosistein, çocuk

\section{ÖZ}

Giriş: Vitamin B12 eksikliği saptanan sağlıklıçocukların klinik ve laboratuvar verilerini değerlendirdiğimiz çalışmamızda Vitamin B12 eksikliği tanısında Metilmalonik asit (MMA) ile homosistein düzeylerinin yararlarına ve tanıda karşılaşılan güçlüklere ve dikkat çekildi.

Gereç ve Yöntem: Serum kobalamin düzeyleri 126.5 pg/ ml'nin altında olan toplam 70 sağlıklı çocuk çalışmaya dahil edildi. Yaş, cinsiyet, serum B12 vitamini, idrar MMA, plazma homosistein düzeyleri, beyaz küre ve trombosit sayıları, hemoglobin, ortalama eritrosit hacmi (Mean Corpuscular Volume, MCV), ortalama trombosit hacmi (mean platelet volume, MPV), folik asit ve ferritin düzeyleri geriye dönük olarak incelendi. Vitamin B12 düzeylerini MMA ve homosistein düzeyleri ile karşılaştırmak için korelasyon analizi kullanıldı.

Bulgular: Sağlıklı çocuklarda ortalama yaş $8.21 \pm 6.15$ yı olup \%6.29'unda B12 vitamini eksikliği saptandı. Kobalamin seviyeleri 50-126 pg/ml arasında değişmekteydi ve ortalama $102.57 \pm 18.97 \mathrm{pg} / \mathrm{ml}$ olarak saptandı. İdrar MMA ve serum

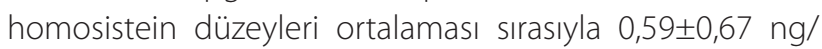

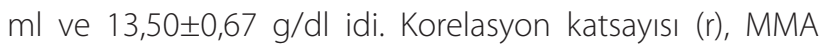
için -0.342 , homosistein için -0.437 'ydi ve orta derecede negatif olarak değerlendirildi. 36 hastada MMA seviyeleri, 48 hastada homosistein seviyeleri normaldi.

Sonuç: Vitamin B12 eksikliği çocuklarda yaygın bir mikro besin eksikliğidir. Özellikle yüksek MMA ve homosistein düzeyleri gibi tipik laboratuvar bulguları göstermeyen sağlıklı çocuklarda vitamin B12 eksikliğinin teşhisi zor olabilir.

Anahtar Kelimeler: B12 vitamini, kobalamin, metilmalonik asit, homosistein, çocuk 


\section{INTRODUCTION}

Cobalamin (vitamin B12) is a water-soluble vitamin whose primary source is animal products. A small amount is stored in the liver. Inadequate intake, intestinal malabsorption, and the use of some drugs can cause deficiency. This can lead to many disorders in various organ systems, especially megaloblastic anemia, as well as neurological and psychiatric disorders. It is essential to diagnose and treat vitamin B12 deficiency in childhood because delay in treatment may cause complications such as severe anemia and other lasting complications that cause irreversible neurological damage (1-3).

The diagnosis of vitamin B12 deficiency is typically made by measuring serum vitamin B12 levels to detect megaloblastic anemia. However, the clinical condition of most patients may not be very clear. Low vitamin B12 levels can be found without specific symptoms or anemia (false low), and normal vitamin B12 levels can be found despite strong clinical findings (false normal). Clinical findings for patients represent the most crucial factor in evaluating serum vitamin B12 levels because there is no "gold standard" diagnostic test to identify the deficiency (4). Urine MMA and plasma homocysteine levels, which are intermediate products of B12 and folate metabolism, may help in the diagnosis. However, these metabolic tests are not commonly used at present. In addition, the cut-off values of these tests indicating B12 deficiency are not clear and may differ between different laboratories $(4,5)$.

In this study, we evaluated the clinical and laboratory data of previously healthy cases who applied to the pediatric outpatient clinic with various complaints and were found to have vitamin B12 deficiency. The difficulties encountered in the diagnosis have been pointed out.

\section{MATERIAL AND METHOD}

The study was carried out with the permission of Ankara City Hospital No. 2 Clinical Research Ethics Committee (Dated: 08/12/2021, Decision No: E2-21-943). All procedures were carried out in accordance with the ethical rules and the principles of the Declaration of Helsinki.

Healthy children who applied to the pediatric outpatient clinic of Ankara City Hospital with various complaints and whose vitamin B12 levels were found to be low for screening purposes were evaluated over the period June 2018 - June 2019. The age and gender of these patients were recorded. In addition, serum vitamin B12, urine MMA, plasma homocysteine, white blood cell, hemoglobin, thrombocyte, MCV, MPV, folic acid, and ferritin levels were obtained retrospectively from the hospital's medical records. All of the laboratory data were obtained in the biochemistry and metabolism laboratory of our hospital. The chemiluminescence method (Beckman Coulter Dxl 800) was used in measuring serum vitamin B12 and folic acid levels, plasma homocysteine levels were measured with the chemiluminescence immunoassay method (Immulite 2000, Siemens Diagnostics), and urine MMA levels were measured with the gas chromatography-mass spectrometry method (GCMS QP 2010SE, Shimadzu). Serum B12 levels below the laboratory cut-off level of $126.5 \mathrm{pg} / \mathrm{ml}$ were defined as deficiency. A hemoglobin result of below $11 \mathrm{~g} / \mathrm{dl}$ was defined as anemia, a leukocyte value of below $4500 / \mathrm{mm}^{3}$ as leukopenia, and a platelet count of below $150 \times 10^{3} / \mathrm{mm}^{3}$ as thrombocytopenia.

Laboratory-specific and assay-specific cut-offs were used for urine MMA and plasma homocysteine levels. An increased MMA level was accepted as $0.4 \mathrm{ng} / \mathrm{ml}$, and an increased homocysteine level as above $15 \mathrm{~g} / \mathrm{dl}$. Patients with a chronic disease (e.g., malignancy, malabsorption syndromes like celiac disease, inflammatory bowel diseases) or those using drugs that could affect vitamin B12 levels, such as metformin, proton pump inhibitors, and patients whose data could not be obtained were not included in the study.

Statistical analyses were performed using the SPSS 20 package program. Pearson's correlation analysis test was used to compare vitamin B12 and other parameters. Results of descriptive analyses were reported in terms of minimum, maximum, and mean \pm standard deviation $(\mathrm{X} \pm \mathrm{SD})$ for continuous variables, while non-continuous values were reported in numbers $(n)$ and percentages (\%). Differences were regarded as statistically significant at $\mathrm{p}<0.05$.

\section{RESULTS}

During the course of the study, the vitamin B12 levels of 1874 pediatric cases were evaluated (male; 991, 52.8\%, female; $883,47.1 \%)$. Vitamin B12 deficiency was found in $118(6.29 \%)$ of these cases. The study group consisted of 70 (37 male, 33 female) patients who were found to have Vitamin B12 deficiency and whose urinary MMA and plasma homocysteine levels were obtained. The ages of the subjects in the study group ranged from 3 months to 17.5 years, the mean age being $8.21 \pm 6.15$ years. Vitamin B12 levels ranged from $50-126 \mathrm{pg} / \mathrm{ml}$, with a mean of $102.57 \pm 18.97 \mathrm{pg} / \mathrm{ml}$. There was no significant difference between the groups regarding age and gender $(p>0.05)$. The most common complaints were constitutional complaints such as loss of appetite and fatigue. The complaints in the study group are summarized in Table 1. 
Table 1: Complaints of study group

\begin{tabular}{lll} 
Complaints & & $\mathbf{n , ( \% )}$ \\
\hline Constitutional & & \\
& Loss of appetite & $21,(30)$ \\
& Fatigue & $15,(21.4)$ \\
& Recurrent sickness & $7,(10)$ \\
& Development growth & $4,(5.7)$ \\
Neurological/psychiatric & \\
& Forgetfulness & $10,(14.2)$ \\
& Developmental delay/regression & $2,(2.8)$ \\
Hematological & Paleness & $7,(10)$ \\
Other & Vomiting/Diarrhea & $3,(4.2)$ \\
TOTAL & & $1,(1.4)$ \\
\hline & & $70,(100)$ \\
\hline
\end{tabular}

Urine MMA levels ranged from 0.14 to $4.63 \mathrm{ng} / \mathrm{ml}$, at a mean of $0.59 \pm 0.67 \mathrm{ng} / \mathrm{ml}$. Serum homocysteine levels were between $0.37-40.32 \mathrm{~g} / \mathrm{dl}$, at a mean of $13.50 \pm 0.67$ $\mathrm{g} / \mathrm{dl}$. The correlation coefficient value $(r)$ was found to be -0.342 and -0.437 , moderately negative for MMA and homocysteine, respectively. MMA levels were normal in 36 patients, and homocysteine levels were normal in 48 patients. The results of ferritin levels in the entire study group, and folic acid levels in 31 patients were obtained. Iron deficiency was found in 42 patients (60\%), and folate deficiency in 2 patients (6.4\%). Other laboratory data are given in Table 2.

Table 2: Clinical and demographic findings of the study group.

\begin{tabular}{lcc} 
Clinical and demographic findings & $\begin{array}{c}\text { Correlation } \\
\text { Coefficient } \\
\text { Value (r) }\end{array}$ \\
\hline Age Mean, Years & $8.21 \pm 6.15$ & NA \\
Gender Male (n, \%) & $37,52.9$ & NA \\
Vitamin B12 Mean pg/ml & $102.57 \pm 18.97$ & NA \\
MMA Mean, ng/ml & $0.59 \pm 0.67$ & -0.342 \\
MMA Min-Max, ng/ml & $0.14-4.63$ & \\
Homocysteine Mean, gr/dl & $13.50 \pm 6.71$ & -0.437 \\
Homocysteine Min-Max, gr/dl & $0.37-40.32$ & \\
Cytopenia (Anemia, Leucopenia & 0,0 & NA \\
and Trombocytopenia (n, \%) & 0,0 & NA \\
Megaloblastosis (n, \%) & $1,1.4$ & NA \\
High MPV (n, \%) & & \\
\hline MMA, metilmalonic asit, MPV, main platelet volume NA, not available & \\
\hline
\end{tabular}

\section{DISCUSSION}

In our study, 70 healthy children who applied to our pediatric outpatient clinic with various complaints and were found to have overt vitamin B12 deficiency were evaluated. No changes in hematological parameters such as cytopenia, macrocytosis, increased MCV and MPV, which are common and prominent in vitamin B12 deficiency, were detected in these patients. In addition, the fact that MMA and homocysteine levels were found to be within normal limits in most of the cases can be considered to contribute to the debate about the reliability of these tests and what the cut-off value of vitamin B12 in healthy children should be.

Vitamin B12 deficiency is common in healthy children, especially in developing countries, as a result of an insufficient intake of animal-sourced foods. Regional differences were found in studies on vitamin B12 deficiency in Turkey. In addition, different frequencies have been reported depending on the different threshold limits used to define vitamin B12 deficiency. In a study by Wetherilt et al., conducted with 960 healthy school-age children living in urban and rural areas, the frequency of vitamin B12 deficiency was 5.9\% (6). Çolak et al. found the frequency of deficiency to be $16.9 \%$ in their study with 7310 children in Izmir. In this study, the lower limit of vitamin B12 was taken as $200 \mathrm{pg} / \mathrm{ml}$ (7). In another study conducted with a total of 889 participants aged 12-22 years in Diyarbakır, Turkey, the deficiency was found in $14.4 \%$ of the participants when the vitamin B12 cut-off level was taken to be $240 \mathrm{pg} / \mathrm{ml}$ (8). We used $126.5 \mathrm{pg} / \mathrm{ml}$, which is the laboratory and assay-specific cut-off level, for the Vitamin B12 cut-off level in our study. We found the frequency of B12 deficiency in healthy children admitted to the hospital in Ankara to be $6.29 \%$.

The cut-off level of Vitamin B12 may differ between laboratories depending on the measurement method used. Most laboratories use the competitive chemiluminescence test to measure serum vitamin B12 levels (9). This test has an approximate sensitivity of $95 \%$ and $80 \%$ specificity in symptomatic patients and is currently the standard initial diagnostic test for vitamin B12 deficiency. It measures both the "inactive" forms (bound to transcobalamin I-III) and the "active" form (bound to transcobalamin Il-holotranscobalamin) of cobalamin in serum. This chemiluminescence-based method is a widely available, low-cost, automated method based on intrinsic factor binding. Sometimes, normal values may be found in patients clinically thought to have vitamin B12 deficiency, or levels may not be in parallel with the clinical condition of patients with significantly low vitamin B12 levels (subclinical deficiency), as stated in our study (10). In addition, there is an extensive gray range between normal and abnormal values of B12 measured by this method. More importantly, the measurement lacks the specificity and sensitivity required by a powerful diagnostic test $(10,11)$. Because of this, although testing the serum vitamin B12 level remains the first-line test, supporting second-line tests are needed to clarify underlying biochemical/functional uncertainties. MMA and homocysteine are often used for this purpose. Especially in patients who are thought to have vitamin B12 deficiency but whose level is found to be normal, the high MMA level is considered quite significant for a diagnosis of deficiency. Patients with low vitamin B12 with normal MMA and homocysteine levels are considered to have no vitamin B12 deficiency, and no further action is required in these patients (11). In our 
study, in which cases with overt vitamin B12 deficiency were evaluated, MMA was found to be increased in 34 (48.5\%) patients, while homocysteine had increased in 22 (31.4\%) patients. Increases in both were detected in only $12(17.1 \%)$ patients. It is therefore evident that the reliability and cut-off values of these tests should be reviewed in healthy children. Also, if the metabolic values of uncertain/asymptomatic patients are also normal, it would be beneficial to re-study vitamin B12 levels.

Although the measurement of increased MMA and homocysteine levels in the early period of vitamin B12 deficiency is a more sensitive method of screening for vitamin B12 deficiency, the benefit of MMA and homocysteine measurement is controversial, especially in patients with borderline low B12 levels or those who have an absence of clinical findings. In this regard, the measurement of serum holotranscobalamin appears to have promise for first-line testing. Holotranscobalamin, an active vitamin B12 fraction, is more specific than serum vitamin B12 levels and outperforms serum vitamin B12 levels in assessing deficiency based on MMA levels in studies $(11,12)$. Investigating the laboratory's sensitivity and specificity should be reviewed together with a ROC analysis using MMA or an appropriate alternative marker to define proof of the metabolic disorder originating from vitamin B12 deficiency (13). However, the determination of reference ranges by individual laboratories may be difficult because serum cobalamin levels can be affected by many variables such as the manufacturer, diet, and vitamin medications (11).

Since the biochemical pathways of vitamin B12 and folate are closely related, both deficiencies show similar clinical features. The evaluation of vitamin B12 and folate are usually performed together. In actual vitamin B12 deficiency, the serum folate level is usually normal or may be elevated. However, low serum vitamin B12 levels can be detected in the presence of folate deficiency $(14,15)$. In our study, folate levels were obtained in only 31 children, and low levels were found in only two children. The general prevalence of iron deficiency, which is the most common nutritional deficiency in childhood, has been reported to be $15.2-62.5 \%$ in our country (16-18). In our study, this rate was $60 \%$, and anemia was not detected in any of the patients. It is known that the cause of iron deficiency is poor animal nutrition, as is similarly true of vitamin B12 deficiency. It is no surprise then that the two conditions are often found together and associated with a common origin.

There are some limitations in our study. First of all, some data could not be obtained due to the retrospective nature of the research. For example, the response of patients to treatment or hypersegmentation of neutrophils in the peripheral smear could not be evaluated. In addition, the fact that holotranscobalamin is not routinely studied in our clinic, as well as our evaluation of the data of only a limited number of cases at a single site can be counted as other limitations. Nevertheless, our study sheds light on the difficulties that can be experienced in diagnosing vitamin B12 deficiency in children and provides guidance for clinicians.

\section{CONCLUSION}

Vitamin B12 deficiency is a common micronutrient deficiency in childhood. Neurological symptoms and signs may develop without hematological abnormalities such as megaloblastic anemia, and these findings may be permanent. Therefore, the recognition and early treatment of vitamin B12 deficiency is essential. This can be difficult in children who do not display typical laboratory findings particularly elevated MMA and homocysteine. In this regard, national quality assessments and standardization of laboratories will be beneficial.

\section{ETHICAL DECLARATIONS}

Ethics Committee Approval: The study was carried out with the permission of Ankara City Hospital No. 2 Clinical Research Ethics Committee (Dated: 08/12/2021, Decision No: E2-21-943).

Informed Consent: Because the study was designed retrospectively, no written informed consent form was obtained from patients.

Referee Evaluation Process: Externally peer-reviewed.

Conflict of Interest Statement: The authors have no conflicts of interest to declare.

Financial Disclosure: The authors declared that this study has received no financial support.

Author Contributions: All of the authors declare that they have all participated in the design, execution, and analysis of the paper, and that they have approved the final version.

\section{REFERENCES}

1. Bunn H. F. Vitamin B12 and pernicious anemia--the dawn of molecular medicine. New Engl J Med 2014;370(8):773-6.

2. Green R. Vitamin B12 deficiency from the perspective of a practicing hematologist. Blood 2017;129(19):2603-11.

3. Kocaoglu C, Akin F, Caksen H, Boke SB, Arslan S, Aygun S. Cerebral atrophy in a vitamin B12-deficient infants of a vegetarian mother. J Health Popul Nutr 2014;32:367-71.

4. Devalia V, Hamilton MS, Molloy AM, et al. Guidelines for the diagnosis and treatment of cobalamin and folate disorders. $\mathrm{Br} J$ Haematol 2014;166(4):496-513.

5. Stabler SP. Vitamin B12 deficiency. New Engl J Med 2013;368(2):149-60.

6. Wetherilt $\mathrm{H}$, Ackurt $F$, Brubacher $\mathrm{G}$, et al. Blood vitamin and mineral levels in 7-17 years old Turkish children. Int J Vit Nutr Res 1992;62(1):21-9.

7. Çolak A, Akşit MZ, Şimşek N, et al. Iron, Folate and Vitamin B12 Status of Children and Adolescents:Single Center Study in the Aegean Region. J Dr. Behcet Uz Children's Hospital 2019;9(3). 
8. Öncel K, Özbek MN, Onur H, et al. Diyarbakır ilindeki çocuklarda ve adölesanlarda B12 vitamin ve folik asit düzeyleri. Dicle Tıp Derg 2006;33(3):163-9.

9. Oberley MJ, Yang DT. Laboratory testing for cobalamin deficiency in megaloblastic anemia. Am J Hematol 2013;88(6):522-6.

10. Carmel R, Sarrai M. Diagnosis and management of clinical and subclinical cobalamin deficiency:advances and controversies. Curr Hematol Rep 2006;5(1):23-33.

11. Devalia V, Hamilton MS, Molloy AM. Guidelines for the diagnosis and treatment of cobalamin and folate disorders. Br J Haematol 2014;166(4):496-513.

12. Nexo E, Hoffmann-Lücke E. Holotranscobalamin, a marker of vitamin B-12 status:analytical aspects and clinical utility. Am J Clin Nutr 2011;94(1);359-65.

13. Valente E, Scott JM, Ueland PM, et al. Diagnostic accuracy of holotranscobalamin, methylmalonic acid, serum cobalamin, and other indicators of tissue vitamin B12 status in the elderly. Clin Chem 2011;57(6):856-63.

14. Froese DS, Fowler B, Baumgartner MR. Vitamin B12, folate, and the methionine remethylation cycle-biochemistry, pathways, and regulation. J Inherit Metab Dis 2019;42(4):673-85.

15. Allen RH, Stabler SP, Savage DG, et al. Metabolic abnormalities in cobalamin (vitamin B12) and folate deficiency. FASEB 1993;7(14):1344-53.

16. Sarper N. Demir Eksikliği Anemisi. Türkiye Klinikleri 2009;78(1):614.

17. Gür E, Yildiz I, Celkan T, et al. Prevalence of anemia and the risk factors among schoolchildren in Istanbul. J Trop Pediatr 2005;51(6):346-50.

18. Özdemir N. Iron deficiency anemia from diagnosis to treatment in children. Turk Pediatri Arsivi. 2015;50(1):11-19. 